IZADP No. 2232

Earnings-Related Severance Pay

Laszlo Goerke

July 2006 


\title{
Earnings-Related Severance Pay
}

\author{
Laszlo Goerke \\ University of Tübingen, \\ CESifo and IZA Bonn
}

\section{Discussion Paper No. 2232 \\ July 2006}

\author{
IZA \\ P.O. Box 7240 \\ 53072 Bonn \\ Germany \\ Phone: +49-228-3894-0 \\ Fax: +49-228-3894-180 \\ Email: iza@iza.org
}

\begin{abstract}
Any opinions expressed here are those of the author(s) and not those of the institute. Research disseminated by IZA may include views on policy, but the institute itself takes no institutional policy positions.

The Institute for the Study of Labor (IZA) in Bonn is a local and virtual international research center and a place of communication between science, politics and business. IZA is an independent nonprofit company supported by Deutsche Post World Net. The center is associated with the University of Bonn and offers a stimulating research environment through its research networks, research support, and visitors and doctoral programs. IZA engages in (i) original and internationally competitive research in all fields of labor economics, (ii) development of policy concepts, and (iii) dissemination of research results and concepts to the interested public.
\end{abstract}

IZA Discussion Papers often represent preliminary work and are circulated to encourage discussion. Citation of such a paper should account for its provisional character. A revised version may be available directly from the author. 
IZA Discussion Paper No. 2232

July 2006

\section{ABSTRACT}

\section{Earnings-Related Severance Pay*}

In an efficiency wage economy, lump-sum severance pay from which shirkers can be excluded raises employment. However, severance payments are usually related to wages. It is shown that earnings-related, mandated severance pay will have ambiguous employment effects if effort can be varied continuously. A substitution of the earnings-related for the lumpsum component reduces employment. Thus, the prevalent form of severance payments in OECD countries might have less advantageous employment effects than previously conjectured.

JEL Classification: J32, J41, J65

Keywords: earnings relationship, efficiency wages, employment, severance pay

Corresponding author:

Laszlo Goerke

Department of Economics

Melanchthonstr. 30

D-72074 Tübingen

Germany

E-mail: Laszlo.Goerke@uni-tuebingen.de

\footnotetext{
* I have benefited from very constructive comments by participants of the workshop on 'European Labour Markets in Perspective' in Regensburg, the $15^{\text {th }}$ annual EALE conference in Seville, the annual meeting of the Verein für Socialpolitik in Dresden, by seminar participants in St. Gallen, Mannheim (ZEW), and Bonn (IZA), and by an anonymous referee. Moreover, I am grateful to the German Research Foundation (DFG) for financial support under grant no. 454, "Heterogeneous Labor: Positive and Normative Aspects of the Skill Structure of Labor".
} 


\section{Introduction}

What are the employment effects of severance pay? One answer stresses the fact that severance payments represent a tax on dismissals. This tax increases employment for a given wage in the bad state of nature since there are fewer dismissals. However, employment declines in the good state because firms hire fewer workers. Consensus seems to be that the overall labour demand effects of pure firing costs are small (Bentolila and Bertola 1990, Bertola 1999, Pissarides 2001). Another response emphasises that severance payments constitute a transfer. Such a transfer can induce a wage adjustment which may exactly offset the increase in labour costs due to severance pay so that no change in employment occurs. ${ }^{1}$

The interpretation of severance payments as being akin either to a tax on dismissals or to a transfer to dismissed workers neglects the fact that severance pay may not only alter the payoff of workers, but also their alternative income and, hence, their bargaining position. Taking into account this effect in an individual matching framework, Millard and Mortensen (1997) find negative employment consequences of severance payments. Belot et al. (2006) show that legislated severance payments may be welfare enhancing if they raise the employees' firm-specific human capital. Unemployment declines for sufficiently high levels of severance pay. In an insider-outsider setting, hiring and firing costs generate union bargaining power and can, thus, have negative employment effects (Sanfey 1995, Lindbeck and Snower 2001). In efficiency wage models, severance payments can increase employment as they mitigate the incentives to shirk if disciplinary dismissals do not trigger such transfers (Saint-Paul 1995, Fella 2000, Goerke 2002a). If every worker - regardless of the cause of the job loss obtains severance pay, the employment effects of such transfers will be ambiguous (Staffolani 2002). Finally, if only dismissals for economic reasons entitle to severance pay, while a worker fired for disciplinary reasons can go to court and claim the dismissal not to be justified, then severance pay for such an unfair dismissal may lower employment (GaldónSánchez and Güell 2003).

The aforementioned studies generally assume that severance payments are lump-sum transfers. However, severance pay usually is a function of tenure, age, and especially of the wage prior to dismissal (OECD 1999, 2004). From the analysis of tax variations in imperfectly competitive labour markets it is well known that a change in a pure level variable can have a different employment effect than a variation in a wage-dependent one. ${ }^{2}$ This is because a higher tax level only has an income effect, while a higher marginal rate also implies a substitution impact. Modelling severance pay as a lump-sum transfer may, accordingly, neglect its substitution effect and give rise to inadequate predictions of its employment

\footnotetext{
${ }^{1}$ For according results in various labour market models see, inter alia, Lazear (1990), Burda (1992), Booth (1997), and Garibaldi and Violante (2005).

2 See, for example, Lockwood and Manning (1993) for a model of collective wage determination, Hoel (1990) for an efficiency wage setting, and Pissarides (2000, pp. 210ff) for a search and matching approach. Goerke (2002b) surveys and synthesizes the relevant contributions.
} 
consequences. Therefore, in this paper, lump-sum and earnings-related severance pay are compared and it is investigated how altering the composition affects employment.

The analysis presumes firms which pay efficiency wages to restrict shirking. Such an approach allows for a distinction between fair dismissals, i.e. for lack of performance, which do not entitle to severance pay, and unfair dismissals which are here interpreted as those due to reasons beyond a worker's influence and which entail a severance payment. This assumption broadly reflects actual regulations (OECD 1999). Accordingly, only those workers who lose their job for other reasons than shirking are assumed to obtain severance pay. The income effect of mandated severance pay opens up the possibility of positive employment consequences. Since a dichotomous choice of effort does not allow for a substitution effect, Section 2 develops a continuous trade-off between effort and its determinants, extending the set-up by Shapiro and Stiglitz (1984). As discussed in the final section, the framework abstracts from various potential effects of severance pay to isolate the impact of earningsrelated severance payments. Moreover, in order to separate the employment effects of firing costs - i.e. the tax component - and transfers to workers, (implicit) government subsidies for severance payments are allowed for. Section 3 shows that if a unit of wage payments is more costly to the firm than a unit of severance pay, lump-sum severance pay will induce a wage reduction, lower labour costs and thereby raise employment. This mirrors findings for a setting with dichotomous effort decision (Saint-Paul 1995, Fella 2000, Goerke 2002a). An increase in earnings-related severance payments weakens the firm's incentives to reduce wages and mitigates or even reverses the positive employment consequences owing to the level impact. ${ }^{3}$ Finally, Section 3 demonstrates that substituting earnings-related severance payments for lump-sum transfers reduces employment as the income effect no longer occurs, while the substitution impact induces firms to raise the wage. These findings - summarised and discussed in Section 4 - indicate that the type of severance payment prevailing in the OECD may be detrimental to employment, even if shirkers are excluded from such transfers.

\section{An Efficiency Wage Economy with Continuous Effort Function}

Firms are subject to firm-specific shocks and pay efficiency wages since the workers' effort is only imperfectly observable. Firms and workers are risk-neutral, have an infinite life and discount future payoffs with the common rate $r, r>0$.

\subsection{Effort Decision}

The instantaneous utility of a worker equals the difference between income and effort e which, without loss of generality, is restricted to the interval $[0,1]$. Given the wage, the worker

\footnotetext{
3 An exception to the general approach of modelling severance pay as lump-sum transfer in efficiency wage models is Staffolani (2002) who investigates variations in the level of earnings-related severance payments. In the present paper, a change in the composition of severance pay allows for an isolation of the substitution effect.
} 
decides about the level of effort to exert. ${ }^{4}$ Higher effort reduces the probability c(e) of being caught shirking, which automatically results in a dismissal. This probability $\mathrm{c}$ declines with effort e at a decreasing rate, $\mathrm{c}^{\prime}<0<\mathrm{c}^{\prime \prime}$, and $\mathrm{c}^{\prime \prime}=0$, and may be represented, for example, by the function $\mathrm{c}(\mathrm{e})=\mathrm{e}(\mathrm{e}-3) / 2+1$. A dismissal for shirking is feasible for any effort level $\mathrm{e}<1$. The probability of being fired owing to an exogenous, economic shock is given by $b$. The product of the probabilities $b$ and $c(e)$ is sufficiently small, implying $b c(e) \approx 0$.

Severance payments $\Psi$ are only handed out to a worker who loses the job due to exogenous, i.e. economic reasons. The simplest approach to analyse the differential employment consequences of lump-sum and earnings-related severance payments is to assume $\Psi=\mathrm{S}+\sigma \mathrm{w}$, where $S, S \geq 0$, is the lump-sum and $\sigma \mathrm{w}$ the wage-related element, $\sigma \geq 0$, while w represents the wage. Severance payments can either be modelled as transfers per unit of time or as oneoff payments. In the former case, the duration of such transfers must be limited, since otherwise the expected utility of a worker would not be bounded, given an infinite life and a positive probability of regaining and losing a job and, hence, of obtaining further severance pay entitlements in the future. Alternatively, severance pay can be viewed as a single transfer, for example, in the period subsequent to a dismissal. On the one hand, this approach may be regarded as unsatisfactory, as saving is impossible in the traditional Shapiro-Stiglitz model. On the other hand, real world severance pay is akin to a single transfer. In the present paper, the main approach in the literature is followed and severance payments are modelled as onetime payments. Assume, finally, that a dismissal implies at least one period of unemployment. In such a set-up, the utility stream $\mathrm{V}_{\mathrm{t}+1}^{\mathrm{U}, \mathrm{e}}$ of a worker who loses the job for exogenous reasons at the end of period $t$ is increased by severance payments $\Psi_{t+1}$ obtained at the beginning of period $t+1$. Since dismissed shirkers do not obtain severance pay, their utility stream $V_{t}^{U, s}$ is unaffected by severance payments. Given these assumptions, the utility stream $V_{t}^{J}$ of an employed worker at time $\mathrm{t}$ is given by:

$$
r \mathrm{~V}_{\mathrm{t}}^{\mathrm{J}}=\mathrm{w}_{\mathrm{t}}-\mathrm{e}_{\mathrm{t}}+\mathrm{b}\left[\mathrm{V}_{\mathrm{t}+1}^{\mathrm{U}, \mathrm{e}}+\Psi_{\mathrm{t}+1}-\mathrm{V}_{\mathrm{t}+1}^{\mathrm{J}}\right]+\mathrm{c}\left(\mathrm{e}_{\mathrm{t}}\right)\left[\mathrm{V}_{\mathrm{t}+1}^{\mathrm{U}, \mathrm{s}}-\mathrm{V}_{\mathrm{t}+1}^{\mathrm{J}}\right]
$$

When selecting the optimal level of effort, a worker takes as given the utility streams in the event of unemployment $\mathrm{V}_{\mathrm{t}+1}^{\mathrm{U}, \mathrm{e}}, \mathrm{V}_{\mathrm{t}}^{\mathrm{U}, \mathrm{s}}$, of future employment $\mathrm{V}_{\mathrm{t}+1}^{\mathrm{J}}$, and the wage $\mathrm{w}_{\mathrm{t}}$. Maximisation of $V_{t}^{J}$ with respect to current effort $e_{t}$ yields:

$$
\frac{\partial \mathrm{V}_{\mathrm{t}}^{\mathrm{J}}}{\partial \mathrm{e}_{\mathrm{t}}}=-1+\mathrm{c}^{\prime}\left(\mathrm{e}_{\mathrm{t}}\right)\left(\mathrm{V}_{\mathrm{t}+1}^{\mathrm{U}, \mathrm{s}}-\mathrm{V}_{\mathrm{t}+1}^{\mathrm{J}}\right)=0
$$

The optimal choice of effort balances the gain in terms of a reduced probability of being fired with the direct reduction in utility. Since $\mathrm{c}^{\prime \prime}>0$ and $\mathrm{V}_{\mathrm{t}+1}^{\mathrm{U}, \mathrm{S}}-\mathrm{V}_{\mathrm{t}+1}^{\mathrm{J}}<0$ in an interior solution, the value of $e_{t}, 0<e_{t}<1$, which results from (2), maximises the utility stream of an employed worker. This value of $e_{t}$ will also define a global maximum of (1) if $c^{\prime}(0)\left[V_{t+1}^{U, s}-V_{t+1}^{J}\right]>1$

\footnotetext{
${ }^{4}$ Chatterji and Sparks (1991), Altenburg and Straub (1998), or Carter (1998) use qualitatively similar approaches.
} 
and $\mathrm{c}^{\prime}(1)\left[\mathrm{V}_{\mathrm{t}+1}^{\mathrm{U}, \mathrm{s}}-\mathrm{V}_{\mathrm{t}+1}^{\mathrm{J}}\right]<1$ hold. Thus, the reduction in the dismissal probability due to a marginal rise in effort, starting from a value of $e_{t}=0$, must be sufficiently large for a positive effort level to be worthwhile, relative to its marginal costs of unity and the gain from retaining one's job $\left[\mathrm{V}_{\mathrm{t}+1}^{\mathrm{U}, \mathrm{s}}-\mathrm{V}_{\mathrm{t}+1}^{\mathrm{J}}\right]$. Similarly, to rule out the absence of any shirking, a reduction in effort must be less costly than the gain, starting from a value of $e_{t}=1$. A function $c\left(e_{t}\right)$ which is sufficiently convex in the interval $e_{t} \in[0,1]$ satisfies this requirement. Theoretically, it cannot be ruled out that shirking $\left(e_{t}<1\right)$ does not represent an optimal choice. Since imperfect information about effort is the sole reason for unemployment in the present framework, unemployment would no longer exist in the absence of shirking $\left(e_{t}=1\right)$ and the composition of severance payments, for a given level, would have no impact on unemployment. Conversely, if everyone shirked all the time $\left(e_{t}=0\right)$, given the specification of the production function below, no output would be produced. If firms, therefore, do not employ anyone, unemployment would be once again unaffected by the composition of severance pay. The subsequent analysis of the unemployment effects of earnings-related and lump-sum severance payments, accordingly, focuses on an interior solution for the effort level.

Moreover, a steady-state is assumed, in which endogenous variables do not change over time so that the index $t$ can be omitted. Since all workers partially shirk in (a pure strategy) equilibrium, being dismissed for shirking does not convey any information about work behaviour. Moreover, all unemployed find a new job with the same probability and then obtain an instantaneous utility stream $\mathrm{V}^{\mathrm{J}}$. Thus, the utility streams of unemployed shirkers and of workers who have lost their job for exogenous reasons are the same, implying $\mathrm{V}^{\mathrm{U}, \mathrm{e}}=\mathrm{V}^{\mathrm{U}, \mathrm{s}}:=\mathrm{V}^{\mathrm{U}}$. The combination of equations (1) and (2) gives rise to:

$$
[\mathrm{r}+\mathrm{b}+\mathrm{c}(\mathrm{e})]+\mathrm{c}^{\prime}(\mathrm{e})\left\{\mathrm{w}-\mathrm{e}-\mathrm{rV}^{\mathrm{U}}+\mathrm{b} \Psi\right\}=0
$$

While the above considerations apply for an individual worker and, accordingly, a given utility stream $\mathrm{V}^{\mathrm{U}}$ from unemployment, in equilibrium $\mathrm{V}^{\mathrm{U}}$ is determined endogenously. This utility stream from unemployment consists of unemployment benefits $\overline{\mathrm{w}}$ and the expected utility gain from finding a new job, $\mathrm{rV}^{\mathrm{U}}=\overline{\mathrm{w}}+\mathrm{a}\left(\mathrm{V}^{\mathrm{J}}-\mathrm{V}^{\mathrm{U}}\right)$, a being the endogenously determined re-employment probability. A steady-state requires the inflow into unemployment $(b+c(e)) \mathrm{N}$ to equal the outflow $\mathrm{a}(1-\mathrm{N})$, where $\mathrm{N}$ is aggregate employment and labour supply has been normalised to unity. Substituting for $\mathrm{V}^{\mathrm{J}}$ in accordance with equation (1) and for the job acquisition rate a using the steady-state constraint implies:

$$
\mathrm{V}^{\mathrm{U}}=\frac{\overline{\mathrm{w}}(\mathrm{r}+\mathrm{b}+\mathrm{c}(\mathrm{e}))+\mathrm{N} \kappa(\mathrm{e})[\mathrm{w}-\mathrm{e}+\mathrm{b} \Psi]}{\mathrm{r}[\mathrm{r}+\kappa(\mathrm{e})]}, \quad \text { for } \kappa(\mathrm{e}):=\frac{\mathrm{b}+\mathrm{c}(\mathrm{e})}{1-\mathrm{N}}>0
$$

Taking into account these equilibrium repercussions, effort is determined by a modified equation (3), where $\mathrm{V} U$ and $b+c(e)$ have been substituted in accordance with (4):

$$
\Omega:=[r+\kappa(E)]+c^{\prime}(E)\{w-E+b(S+\sigma w)-\bar{w}\}=0
$$


To indicate that the variations in effort are calculated for changes in variables which affect the entire economy, the respective effort level is denoted as E. Differentiation of $\Omega$ yields:

$$
\begin{array}{r}
\Omega_{\mathrm{E}}=\mathrm{c}^{\prime \prime}(\mathrm{E})\{\mathrm{w}-\mathrm{E}+\mathrm{b} \Psi-\overline{\mathrm{w}}\}+\frac{\mathrm{Nc}^{\prime}(\mathrm{E})}{1-\mathrm{N}} \\
\Omega_{\mathrm{N}}=\frac{\kappa(\mathrm{E})}{1-\mathrm{N}}>0 \\
\Omega_{\mathrm{W}}=\mathrm{c}^{\prime}(\mathrm{E})(1+\mathrm{b} \sigma)<0
\end{array}
$$

While the sign of $\Omega_{\mathrm{E}}$ is theoretically ambiguous, since higher effort reduces the utility from unemployment $\mathrm{V}^{\mathrm{U}}$ and also $\kappa(\mathrm{E})$, effort $\mathrm{E}$ only rises with the wage $\left(\mathrm{E}_{\mathrm{W}}=-\Omega_{\mathrm{W}} / \Omega_{\mathrm{E}}>0\right)$ and declines with employment $\left(\mathrm{E}_{\mathrm{N}}=-\Omega_{\mathrm{N}} / \Omega_{\mathrm{E}}<0\right)$ for $\Omega_{\mathrm{E}}>0$. This sign restriction is assumed to hold henceforth. If it were not warranted, an equilibrium with minimal wages and maximal employment would exist. Accordingly, the present framework can only help to analyse the unemployment effects of earnings-related severance pay if $\Omega_{\mathrm{E}}>0$ applies.

\subsection{Firm Behaviour}

The number of firms in the economy is fixed and normalised to unity. As a consequence, the firm's maximisation problem can be expressed in terms of aggregate variables, thereby bypassing any aggregation issues. The timing of decisions is as follows: at the beginning of a period, the firm sets a wage which determines the level of effort and also chooses employment. Production occurs and workers exert their optimal level of effort. At the end of the period, those workers who have been detected shirking are dismissed. Moreover, an exogenously given number of jobs become unprofitable, so that those workers who have performed the relevant tasks become superfluous. They are dismissed for economic reasons and obtain severance pay. In order to allow for a steady-state, the same number of jobs as have been closed down are re-opened at the beginning of the next period. Hiring workers for these new jobs is free and has to take place from the pool of unemployed.

The firm's production function $\mathrm{f}$ is strictly concave in effective employment $\mathrm{EN}$ ( $\mathrm{f}^{\prime}(\mathrm{EN})>0$, $\left.\mathrm{f}^{\prime \prime}<0\right)$ and requires a positive amount of effective employment for any output to be produced $(\mathrm{f}(0)=0)$. The capital stock is fixed and its costs are normalised to zero. The firm pays taxes $\tau$ , $\tau \geq 0$, on its payroll. These taxes include all wage-related, non-wage costs of employment. Given these assumptions, expected profits are invariant over time and the firm's behaviour can be derived from the maximisation of its expected profits per period.

According to the tax interpretation of severance payments, dismissals may involve costs in addition to transfers to workers (Bentolila and Bertola 1990, Burda 1992). However, it is also conceivable for the government to subsidise severance payments, for example, by exempting them from income taxation. Let, thus, the costs of severance pay to the firm be a fraction or 
multiple $\xi$ of the transfers which workers receive, $0 \leq \xi$. If $\xi=1$ holds, there will neither be additional costs nor subsidies. Hence, profits per period can be expressed as:

$$
\Pi=\mathrm{f}(\mathrm{NE})-\mathrm{N}[\mathrm{w}(1+\tau)+\mathrm{b} \Psi \xi]
$$

The firm chooses wages $\mathrm{w}$ and employment $\mathrm{N}$ to maximise profits. ${ }^{5}$ This yields:

$$
\begin{aligned}
& \frac{\partial \Pi}{\partial \mathrm{N}}=\mathrm{f}^{\prime} \mathrm{E}-\mathrm{w}(1+\tau)-\mathrm{b} \Psi \xi=0 \\
& \frac{\partial \Pi}{\partial \mathrm{w}}=\mathrm{N}\left[\mathrm{f}^{\prime} \mathrm{E}_{\mathrm{W}}-(1+\tau)-\mathrm{b} \sigma \xi\right]=0
\end{aligned}
$$

The second-order condition requires the effort function to be strictly concave in the wage, implying $\mathrm{E}_{\mathrm{WW}}<0$. As shown in the appendix, this requirement is warranted for $\Omega_{\mathrm{E}}>0$. From the inspection of equation (10) it is, moreover, obvious that pure firing costs lower employment.

\subsection{Equilibrium}

The equilibrium of the economy can be defined by the firm's first-order condition (10) and a modified Solow-condition (Solow 1979), resulting from equations (10) and (11):

$$
\begin{gathered}
\mathrm{F}:=\mathrm{E}(\mathrm{w}, \mathrm{N}, \Psi) \mathrm{f}^{\prime}(\mathrm{E}(\mathrm{w}, \mathrm{N}, \Psi) \mathrm{N})-\mathrm{w}(1+\tau)-\mathrm{b} \xi(\mathrm{S}+\sigma \mathrm{w})=0 \\
\mathrm{H}:=\frac{\mathrm{E}(\mathrm{w}, \mathrm{N}, \Psi)}{\mathrm{E}_{\mathrm{W}}(\mathrm{w}, \mathrm{N}, \Psi, \sigma)}-\mathrm{w}-\frac{\mathrm{b} \xi \mathrm{S}}{1+\tau+\mathrm{b} \xi \sigma}=0
\end{gathered}
$$

The endogenous variables are the wage $\mathrm{w}$ and employment $\mathrm{N}$, the exogenous ones are the determinants of severance payments, $S$ and $\sigma$. Differentiation of $F$ with respect to wages and employment yields:

$$
\begin{aligned}
& \mathrm{F}_{\mathrm{W}}=\mathrm{f}^{\prime \prime} \mathrm{ENE} \mathrm{E}_{\mathrm{W}}+\mathrm{f}^{\prime} \mathrm{E}_{\mathrm{W}}-1-\tau-\mathrm{b} \xi \sigma=\mathrm{f}^{\prime \prime} \mathrm{ENE}_{\mathrm{W}}<0 \\
& \mathrm{~F}_{\mathrm{N}}=\mathrm{f}^{\prime \prime} \mathrm{E}^{2}+\left(\mathrm{f}^{\prime \prime} \mathrm{EN}+\mathrm{f}^{\prime}\right) \mathrm{E}_{\mathrm{N}}<0, \text { for } \mathrm{f}^{\prime \prime} \mathrm{EN}+\mathrm{f}^{\prime} \geq 0 .
\end{aligned}
$$

Moreover, given the restrictions on $\mathrm{c}(\mathrm{E})$, a sufficient condition for $\mathrm{H}_{\mathrm{W}}$ and $\mathrm{H}_{\mathrm{N}}$ to be positive is that at least $50 \%$ of the labour force is employed (see appendix). Equations (12) and (13) will define a stable equilibrium if the labour demand schedule has a steeper slope in the wage-

\footnotetext{
5 It could be argued that the firm can promise workers severance payments in the case of a dismissal. However, given a dismissal, a firm always has an incentive to renege. Therefore, severance payments are assumed to be set by a legal institution and to represent an exogenous variable from the firm's perspective. In the present model, severance pay is, therefore, formally equivalent to fully experience-rated unemployment benefits to which only non-shirkers are entitled.

6 This sign restriction, which has usually been made (Akerlof and Yellen (1985), Pisauro (1991), and Chang et al. (1999)), and is also assumed subsequently, holds, for example, for a Cobb-Douglas production function.
} 
employment space than the Solow-condition, so that the determinant D of the system is negative, $\mathrm{D}:=\mathrm{F}_{\mathrm{N}} \mathrm{H}_{\mathrm{W}}-\mathrm{H}_{\mathrm{N}} \mathrm{F}_{\mathrm{W}}<0$, as assumed in Figure 1 and also for the subsequent analysis.

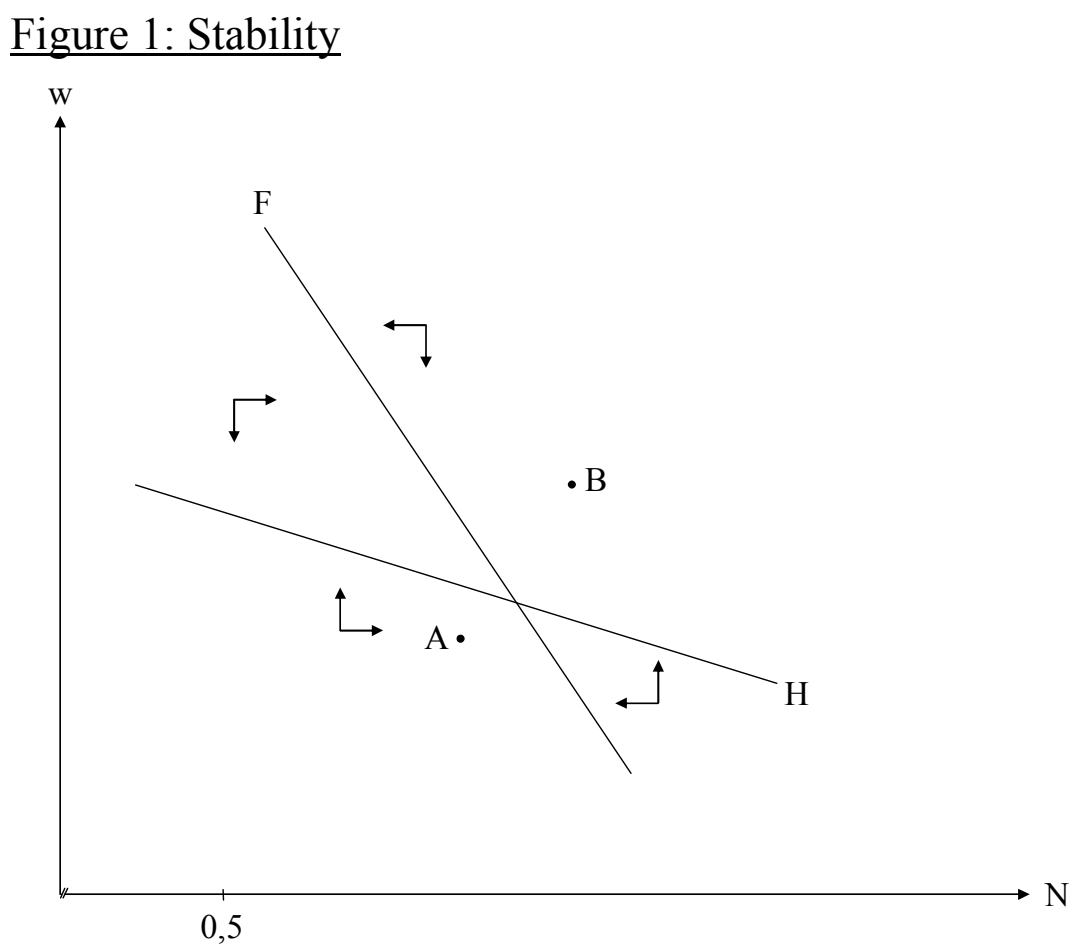

If a wage-employment combination below (above) the labour demand schedule $\mathrm{F}$ results, for example because a change in an exogenous variable shifts the labour demand schedule and the Solow-condition so that the original steady-state equilibrium is no longer situated at the intersection of the two schedules A (or B) in Figure 1, firms can increase their profits by raising (or lowering) employment. Accordingly, a horizontal movement from A, respectively B, towards the labour demand schedule occurs. A wage-employment combination below (above) the wage setting schedule $\mathrm{H}$ implies that the efficiency wage is too low (high) for a given level of employment. Thus, firms could increase profits by raising (lowering) the efficiency wage and a vertical movement from $\mathrm{A}$, respectively $\mathrm{B}$, towards the wage setting schedule results. These adjustments will guarantee the stability of the equilibrium if the slope of the wage setting schedule $\mathrm{H}$ falls short of the slope of the labour demand schedule $\mathrm{F}$ in absolute value, as it is depicted in Figure 1, where linear schedules have been assumed for simplicity.

\section{Employment Effects of Severance Payments}

Initially, the consequences of a higher lump-sum component $\mathrm{S}$ of severance pay are analysed. Subsequently, an increase in the earnings-related element $\sigma$ is looked at. Both investigations 
prepare for the main issue at stake, the substitution of the earnings-related for the lump-sum component of severance pay.

\subsection{Lump-sum Severance Payments}

The effects of lump-sum severance payments on the labour demand schedule $\mathrm{F}$ and the modified Solow-condition $\mathrm{H}$ can be ascertained from equations (12) and (13):

$$
\begin{aligned}
& F_{S}=\left(f^{\prime \prime} E N+f^{\prime}\right) E_{S}-b \xi \\
& H_{S}=\frac{E_{S} E_{W}-E E_{W S}}{\left(E_{W}\right)^{2}}-\frac{b \xi}{1+\tau+b \xi \sigma}
\end{aligned}
$$

In order to evaluate these expressions, the impact of wages $\mathrm{w}$ and lump-sum severance pay $\mathrm{S}$ on effort $E$ has to be known. According calculations using equations (5), (6), and (8) show that $\mathrm{E}_{\mathrm{S}} / \mathrm{E}_{\mathrm{W}}=\Omega_{\mathrm{ES}} / \Omega_{\mathrm{EW}}=\mathrm{E}_{\mathrm{WS}} / \mathrm{E}_{\mathrm{WW}}=\mathrm{b} /(1+\mathrm{b} \sigma):=\beta$ holds (see also the appendix). Since $\mathrm{F}_{\mathrm{W}}, \mathrm{D}<0$ and $\mathrm{H}_{\mathrm{W}}>0$, substitution in (16) and (17), also using $\gamma:=1+\tau+\mathrm{b} \xi \sigma>0$, yields:

$$
\frac{\mathrm{dN}}{\mathrm{dS}}=\frac{\mathrm{H}_{\mathrm{S}} \mathrm{F}_{\mathrm{W}}-\mathrm{F}_{\mathrm{S}} \mathrm{H}_{\mathrm{W}}}{\mathrm{D}}=\frac{\beta(\tau+1-\xi)}{\mathrm{D}}\left[\frac{\mathrm{F}_{\mathrm{W}}}{\gamma}-\mathrm{H}_{\mathrm{W}}\right]
$$

The findings are summarised in:

\section{Proposition 1}

If the costs of wage and severance payments are the same $(\tau=\xi-1)$, mandated, lump-sum severance payments $\mathrm{S}$ will have no employment effects. If a unit of wage payments is more costly than a unit of severance pay $(\tau>\xi-1)$, lump-sum severance pay $\mathrm{S}$ will raise employment.

Garibaldi and Violante (1999) calculate that the non-transfer component of firing costs in Italy and the UK is less than $15 \% .{ }^{7}$ Given an effective tax rate on labour in many countries in the range of $30 \%$ to $40 \%$, this suggests $\tau>\xi-1$ and that mandated severance payments raise the number of jobs. ${ }^{8}$ To provide an intuition for this prediction assume, first, that the costs of wage and severance payments are the same $(\tau=\xi-1)$, entailing the absence of any employment effect. Severance payments are only received by workers who have not been caught shirking. The wage reaction to the change in severance payments is determined by the modified Solow-condition (13). Since $\mathrm{E}_{\mathrm{S}} / \mathrm{E}_{\mathrm{W}}=\mathrm{E}_{\mathrm{WS}} / \mathrm{E}_{\mathrm{WW}}=\beta$ holds, a rise in lump-sum severance payments induces a wage reduction by $\beta$, for a given level of employment, as the combination of $\mathrm{H}_{\mathrm{S}}$ (see equation (17)) and $\mathrm{H}_{\mathrm{W}}$ (derived in the appendix) shows. This implies

\footnotetext{
${ }^{7}$ In a later study also for Italy, Garibaldi and Violante (2005) find that dismissal cases which go to trial and, thus, involve an above average fraction of firing costs, still entail a transfer component of at least two-thirds of the entire costs of a dismissal.

8 The assumption of $\tau>\xi-1$ is discussed further in the concluding section.
} 
constant labour costs per worker $\mathrm{w}+\mathrm{b}[\mathrm{S}+\sigma \mathrm{w}]$. Moreover, for a given level of employment, workers provide the same level of effort since $\mathrm{dE} / \mathrm{dS}=\mathrm{E}_{\mathrm{S}}+\mathrm{E}_{\mathrm{W}} \mathrm{dw} / \mathrm{dS}=0$. If effort and labour costs are constant, employment will be the same as before the increase in severance payments. Lazear's (1990) finding that a wage adjustment may exactly offset the increase in labour costs due to severance pay can, hence, also be replicated in an efficiency wage setting (see also Goerke 2002a).

Suppose, second, that the payroll tax rate is positive or that the government subsidises severance payments. More generally, this implies that a unit of wage payments is more costly than a unit of severance pay $(\tau>\xi-1)$. For a given level of employment it can be derived from the modified Solow-condition that wages fall more strongly with severance pay than in the absence of payroll taxes or subsidies. This is because a positive payroll tax or subsidies for severance payments make wages more costly, relative to severance pay. If wage costs fall more strongly than expected expenditure for severance pay rises, expected labour costs will decline and employment will go up. Higher employment increases the utility stream from unemployment $\mathrm{V}^{\mathrm{U}}$. The ensuing reductions in effort and employment only mitigate but do not reverse the positive employment effect of lump-sum severance pay.

\section{Figure 2: Higher lump-sum Severance Pay}

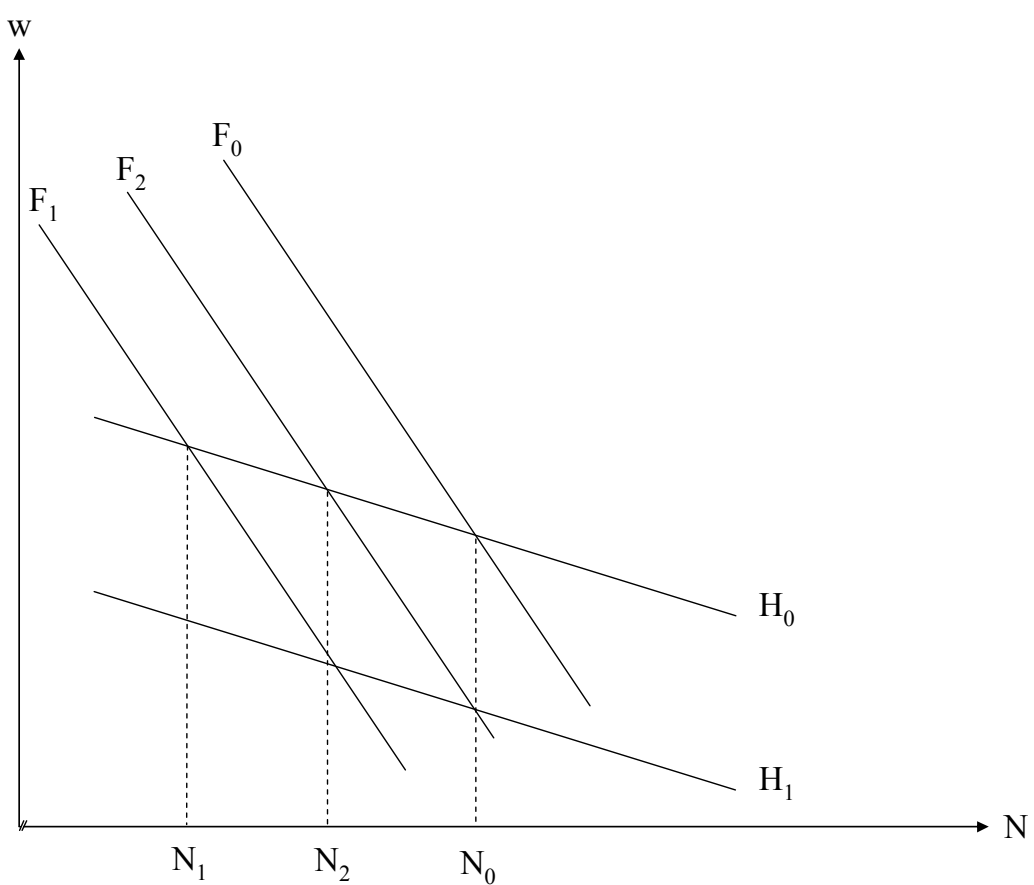

In terms of Figure 2, the increase in expected labour costs owing to higher lump-sum severance pay shifts the labour demand schedule from $F_{0}$ to $F_{1}$. Employment declines from $\mathrm{N}_{0}$ to $\mathrm{N}_{1} \cdot{ }^{9}$ A higher expected income of workers - for a given wage - raises their productivity

\footnotetext{
9 Note that changes in the slope of the labour demand and wage setting schedule due to a variation in the components of severance payments are ignored in the figures as they do not alter the intuition for the findings.
} 
and, therefore, labour demand. Thus, the labour demand schedule shifts back to $F_{2}$, entailing an employment level $\mathrm{N}_{2}$. Finally, a wage adjustment takes place, pushing the wage setting schedule downwards from $\mathrm{H}_{0}$ to $\mathrm{H}_{1}$. In Figure 2, the cost, productivity and wage moderation effects are presumed to cancel out, as $\mathrm{F}_{2}$ and $\mathrm{H}_{1}$ intersect at the original employment level $\mathrm{N}_{0}$, which is determined by the intersection of $\mathrm{H}_{0}$ and $\mathrm{F}_{0}$. Hence $\mathrm{dN} / \mathrm{dS}=0$ results which implies $\tau+1-\xi=0$. If $\tau>\xi-1$ applies, the wage setting schedule will shift down further than $\mathrm{H}_{1}$, so that employment rises.

If dismissing a worker for economic reasons - and, thus rehiring another one in the future entails positive hiring costs, in contrast to the assumption made above, an increase in employment due to higher lump-sum severance pay may become less likely. To illustrate, suppose that hiring costs are proportional to dismissal costs, i.e. severance payments $\Psi$. In this case, the parameter $\xi$ also includes hiring costs and it becomes less likely that $\tau>\xi-1$ holds, even if the government implicitly subsidises severance payments.

\subsection{Earnings-Related Severance Payments}

In OECD countries, severance payments are usually defined as a linear function of the wage which has been paid prior to the dismissal, although minimum payments are also well-known (OECD 2004). An increase in the lump-sum component $S$ can be interpreted as a higher minimum payment. The question, thus, is whether the same qualitative employment effects as for minimum payments occur when strengthening the earnings-related component. From equation (5), and employing the same procedure as it has been used for the calculation of $E_{S}$ and $\mathrm{E}_{\mathrm{WS}}$, one obtains that $\mathrm{E}_{\sigma}=\mathrm{E}_{\mathrm{W}} \mathrm{w} \beta$ and $\mathrm{E}_{\mathrm{W} \sigma}=\left[\mathrm{E}_{\mathrm{WW}} \mathrm{W}+\mathrm{E}_{\mathrm{W}}\right] \beta$ hold. This gives rise to the following relationship between $\mathrm{H}_{\mathrm{W}}$ and $\mathrm{H}_{\sigma}$ :

$$
\mathrm{H}_{\sigma}=\beta\left[\mathrm{H}_{\mathrm{W}} \mathrm{W}-\frac{\mathrm{b} \xi \mathrm{S}(\tau+1-\xi)}{\gamma^{2}}\right]
$$

Moreover, note that $\mathrm{F}_{\sigma}=\mathrm{F}_{\mathrm{Sw}}$. Using the same methodology as for the calculation of the effects of a rise in $\mathrm{S}$, the variation in employment owing to an increase in the earnings-related component of severance payments is found to be:

$$
\frac{\mathrm{dN}}{\mathrm{d} \sigma}=-\frac{\beta(\tau+1-\xi)}{\mathrm{D}}\left[\mathrm{H}_{\mathrm{W}} \mathrm{W}+\frac{\mathrm{F}_{\mathrm{W}} \mathrm{b} \xi \mathrm{S}}{\gamma^{2}}\right]
$$

Since $\mathrm{F}_{\mathrm{W}}$ and $\mathrm{H}_{\mathrm{W}}$ have the opposite sign, the employment effects of earnings-related severance pay are generally ambiguous. This is due to the potentially wage-increasing impact of a rise in the earnings-related component $\sigma$. The results are summarised in: 


\section{Proposition 2}

If the costs of wage and severance payments to the firm are the same $(\tau=\xi-1)$, respectively differ $(\tau \neq \xi-1)$, mandated, earnings-related severance payments $\sigma$ will have no, respectively ambiguous employment effects. If a unit of wage payments is more costly than a unit of severance pay $(\tau>\xi-1)$, and if there is no minimum payment $(\mathrm{S}=0)$ or if severance pay has no cost effect $(\xi=0)$, employment will rise with earnings-related severance payments.

To illustrate the employment effects assume, first, that the costs of wage and severance payments are the same $(\tau=\xi-1)$. In this case, a variation in severance pay induces an adjustment in the efficiency wage so that only the composition but not the level of expected labour costs and a worker's income change. Since the firm and workers are risk-neutral, there are no employment consequences.

Presume, second, that a unit of wage payments is more costly than a unit of severance pay $(\tau>$ $\xi-1)$. In this case, a change in the composition of the worker's expected income alters expected labour costs and employment will vary with an alteration of earnings-related severance pay. In order to determine the direction of these effects, assume lump-sum payments to be absent $(S=0)$. For a given level of employment, the sum of wages and expected severance pay $\mathrm{w}+$ bw $\sigma$ will remain constant if severance payments are increased, because wages decline accordingly. This finding can be derived from the modified Solowcondition (13) which indicates the wage change to be given by $\mathrm{dw} / \mathrm{d} \sigma=-\mathrm{H}_{\sigma} / \mathrm{H}_{\mathrm{W}}=-\mathrm{E}_{\sigma} / \mathrm{E}_{\mathrm{W}}=$ - w $\beta<0$. If the sum of wages and expected severance pay does not vary, effort will remain constant. However, as a unit of wage payments is more costly than a unit of severance pay $(\tau>$ $\xi-1)$, expected labour costs decline. This entails more employment.

If, third, a unit of wage payments is more costly than a unit of severance pay and minimum severance payments exist $(\mathrm{S}>0)$, the wage declines with earnings-related severance pay by less than in the absence of lump-sum payments $(\mathrm{S}=0)$, for a given level of employment. This implies $d w / d \sigma=-H_{\sigma} / H_{W}>-w \beta$ and is the case because lump-sum severance payments, which are qualitatively the same as fixed employment costs, provide an incentive to increase the wage above the level which is optimal for a firm without lump-sum payments (Goerke 1997, Pisauro 2000). This incentive to drive up wages to reduce fixed employment costs is mitigated but not abolished by the increase in earnings-related severance payments. If the wage falls by less than in the absence of lump-sum payments, effort will rise while the net effect on labour costs will be uncertain. Since an increase in labour costs can more than compensate the rise in effort, employment effects of earnings-related severance pay will be ambiguous if earnings-related and lump-sum elements co-exist.

In Figure 3, the combined labour cost and productivity effects shift the labour demand schedule from $F_{0}$ to $F_{2}$ (as in Figure 1). A higher remuneration moves the wage setting schedule downwards to $\mathrm{H}_{1}$. However, since the decrease in wages - for a given employment 
level - is amplified by the stronger earnings relationship, firms reduce wages by less than in a setting with a lower earnings relationship. The wage setting schedule shifts upwards to $\mathrm{H}_{2}$ relative to the case in which lump-sum severance pay is raised - as long as $\mathrm{S}>0$. In Figure 3 , employment is shown to decline from $\mathrm{N}_{0}$ to $\mathrm{N}_{1}$.

\section{Figure 3: Higher Earnings-related Severance Pay}

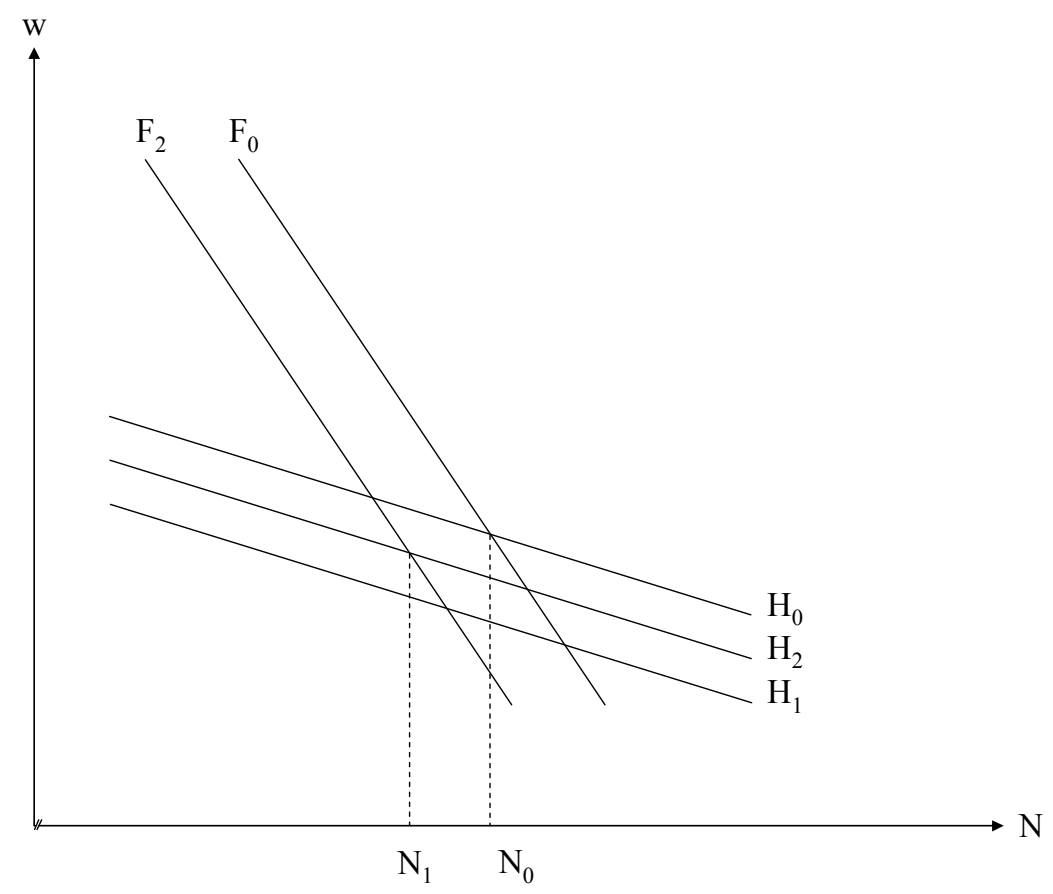

\subsection{Substituting Earnings-Related for Lump-Sum Payments}

In light of the previous results, the issue of the relative employment performance of earningsrelated severance payments arises. Accordingly, a substitution of earnings-related severance payments for lump-sum transfers is analysed, holding constant their overall level at $\bar{\Psi}$. The respective constraint is then given by $\mathrm{K}:=\bar{\Psi}-\mathrm{S}-\mathrm{w} \sigma=0$. Treating the lump-sum payment $\mathrm{S}$, the wage $\mathrm{w}$ and employment $\mathrm{N}$ as endogenous variables, and the earnings-related component $\sigma$ as the exogenous one, while making use of $\mathrm{F}_{\mathrm{SW}}=\mathrm{F}_{\sigma}$ and $\mathrm{H}_{\sigma}=\mathrm{H}_{\mathrm{SW}}-\mathrm{Z}$, for $Z:=\beta(\tau+1-\xi)(w(1+\tau)+b \xi \Psi) / \gamma^{2}$, the variation in employment is found to be:

$$
\frac{\mathrm{dN}}{\mathrm{d} \sigma} \mid \mathrm{d} \bar{\Psi}=0,=\frac{\mathrm{Z}\left[\mathrm{F}_{\mathrm{W}}+\mathrm{F}_{\mathrm{S}} \mathrm{K}_{\mathrm{W}}\right]}{\mathrm{K}_{\mathrm{W}}\left[\mathrm{F}_{\mathrm{N}} \mathrm{H}_{\mathrm{S}}-\mathrm{H}_{\mathrm{N}} \mathrm{F}_{\mathrm{S}}\right]-\mathrm{D}},
$$

where $\mathrm{D}=\mathrm{F}_{\mathrm{N}} \mathrm{H}_{\mathrm{W}}-\mathrm{H}_{\mathrm{N}} \mathrm{F}_{\mathrm{W}}<0$ by the stability argument (see Section 2.3). Assume, first, that earnings-related transfers are substituted for lump-sum severance payments, holding constant their overall level at the initial wage. This implies that severance pay is not adjusted to wage alterations $\left(\mathrm{K}_{\mathrm{W}}=0\right)$. Under this assumption, employment declines for $\tau+1-\xi>0$ because $\mathrm{Z}$ $>0$. The same consequences will result if the introduction of earnings-related severance 
payments is analysed, that is if the employment impact is evaluated at $\sigma=0$. The intuition for the negative employment effect is the following: if the level of severance payments is held constant, effort and labour demand will be unaffected (see equations (5) and (12)). In terms of Figures 2 and 3, the shift of the labour demand schedule from $F_{0}$ to $F_{1}$ and $F_{2}$ does not occur. Raising the earnings-related component $\sigma$ increases marginal effort $E_{W}=-c^{\prime}(E)(1+b \sigma) / \Omega_{E}$. Higher marginal effort induces the firm to raise the efficiency wage, in accordance with equation (13). This wage increase reduces the quantity of labour demanded, despite its effort effect, as can be noted from equations (14) and (15), because wages are chosen optimally by the firm. Therefore, the wage setting schedule $\mathrm{H}$ shifts upwards. Holding constant severance payments at the initial wage ensures that the income effect due to the wage adjustment described above does not counteract the substitution impact.

Suppose, second, that the level of severance payments is not held constant at the initial wage but that wage changes are taken into account $\left(\mathrm{K}_{\mathrm{W}}<0\right)$. In this case, the employment effect becomes ambiguous for $\sigma>0$. This is because a substitution of an earnings-related component of severance pay for the lump-sum part, holding constant its overall level at the initial wage, raises the wage. Thus, if the wage change is taken into account, severance payments increase. In order to retain their original level, for example the lump-sum component has to be lowered, inducing further shifts in the labour demand and wage setting schedule. If a unit of wage payments is more costly than a unit of severance pay $(\tau>\xi-1)$, the reduction in lump-sum severance pay strengthens the negative employment effect (see equation (18)). However, a lower lump-sum component of severance payments induces a rise in the wage. Thus, the impact of a reduction in $\mathrm{S}$ on overall severance payments, $\mathrm{S}+\sigma \mathrm{w}$, is uncertain and depends, inter alia, on the magnitude of the earnings-related component $\sigma$. If, therefore, the consequences of wage adjustments on the level of severance payments are taken into account, the impact of a stronger earnings relationship on expected labour costs can no longer be ascertained. The results are summarised in:

\section{Proposition 3}

Assuming a unit of wage payments to be more costly than a unit of severance pay $(\tau>\xi-1)$, a substitution of the earnings-related for the lump-sum component will reduce employment if severance payments are held constant at the initial wage. Taking into account the wage change, employment will also decline with an according substitution if higher lump-sum severance payments raise the level of these transfers.

\section{Discussion}

This paper assumes that firms cannot make a credible commitment with respect to severance payments and, accordingly, cannot choose such transfers optimally. Instead, the government mandates severance payments. It shows that such legislated severance payments can increase 
employment in an economy in which efficiency wages are paid in order to raise the workers' productivity if severance payments are granted to workers who are dismissed for economic reasons only. In the present framework, positive employment effects require a unit of wage payments to be more costly than a unit of severance pay. Given positive employment effects of lump-sum payments, the impact of earnings-related severance pay is ambiguous, while a substitution of earnings-related for lump-sum payments, holding constant their overall level at the initial wage, reduces employment. Therefore, the prevalent form of severance payments in OECD countries may have less desirable employment effects than previously conjectured. How robust is this result to modifications of the basic model? Three assumptions seem to be potentially noteworthy: first, the restriction on the differential cost effects of wages and severance payments. Second, the assumption of fixed dismissal probabilities and a given job acquisition rate and, third, the exclusion of shirkers from severance pay entitlements.

The assumption of a unit of wages being more costly to firms than a unit of severance pay will always be warranted if the wage wedge, defined as entire wage costs relative to the net wage, exceeds the severance pay wedge, where the latter consists of the complete costs of dismissing a worker, relative to the amount of money received by a dismissed worker. This wedge differential is likely to be positive since severance payments are exempted from social security contributions more often or to a greater extent than wages, can be subject to higher levels of tax exemption or may be taxed at a lower rate, respectively not at all. In addition, the - scarce empirical evidence suggests that firing costs in excess of severance payments are relatively small. More generally, the assumption of a unit of wage payments to be more costly than a unit of severance pay can be interpreted as a means of generating positive employment effects of lump-sum severance pay. Alternatively, it could have been presumed in line with Fella (2000) that severance pay reduces wages in the good state of nature but does not raise them in the bad state, as it occurs in the Lazear (1990) model. Accordingly, severance payments reduce expected labour costs in Fella's set-up. The qualitative employment consequences of lump-sum severance pay granted to non-shirkers would not have been affected by this more elaborate modelling strategy. Therefore, the assumption of a unit of wage payments being more costly than a unit of severance pay not only seems to be broadly warranted empirically, but may also be interpreted as a convenient modelling short-cut.

Assuming fixed dismissal probabilities and a given job acquisition rate obviously excludes the effects of severance payments which arise due to a reduction in labour turnover. Instead, the emphasis has been on the direct cost impact and on the influence on wage formation. This simplification is unlikely to alter the main findings of the paper: first, a given change in lumpsum and earnings-related severance pay would affect dismissal probabilities in the same manner. Therefore, the relative employment effects of the two components of severance pay are unlikely to be affected. Second, the main result of the paper concerns a change in the composition of severance pay. Dismissal probabilities depend on the (given) level of such transfers, which is held constant in the comparative static exercise. Accordingly, it is possible 
to focus on the wage effects of a change in the composition of severance pay. Moreover, any change in the job acquisition rate would then be conditional on the wage induced variation in employment and could, hence, mitigate but not reverse the employment predictions. It should be noted, though, that fixed dismissal and re-employment probabilities imply that positive hiring costs have no impact on firm behaviour. However, hiring costs c. p. reduce the profitability of any dismissal, given a positive probability of a replacement in the future. Thus, the existence of hiring costs may cause positive employment effects of higher lump-sum severance payments to be less likely.

The exclusion of shirkers from severance pay entitlements may, at first sight, be regarded as the most crucial assumption of the analysis. If every dismissal entailed severance payments and the probabilities of dismissing a shirker were unaffected by this modification, severance payments would become akin to one-time unemployment benefits. If severance pay were lump-sum, the employment consequences would, accordingly, be negative. However, the impact of a higher level of earnings-related severance payments on employment is ambiguous (Staffolani 2002), since the income effect may be counteracted by a substitution effect. This is because a stronger earnings relationship will tend to lower marginal effort if every dismissed worker is entitled to severance payments. The firm reacts to the fall in marginal effort by lowering wages, so that the employment impact of higher earnings-related severance pay for all dismissed workers is uncertain. Hence, a stronger earnings relationship of severance pay, holding constant its level, also has uncertain employment consequences. Thus, a similar finding arises as for earnings-related severance payments which only non-shirkers receive. Moreover, granting shirkers severance pay entitlements may alter the firms' dismissal behaviour, causing further uncertainties in the employment consequences.

In reality, the entitlement to severance pay is often restricted to unfair dismissals (cf. OECD 1999, 2004). Thus, firms may have an incentive to mis-declare dismissals due to economic reasons as being the result of having detected a shirker. If such a strategy is successful, the firm saves on severance payments. Similarly, dismissed shirkers have an incentive to claim the dismissal to have been unfair, in order to obtain severance payments. While such misclassifications certainly occur, ${ }^{10}$ they are limited because of reputation effects, particularly for firms, by labour court information about the true reason for a dismissal (if disputes are taken to court), by the costs of court proceedings and the negative impact on the effort choices of those employees who have not been dismissed, since they may not obtain severance payments in the case of a dismissal for economic reasons.

Summing up, the previous discussion suggests that the main result of this paper, according to which the employment impact of strengthening the earnings relationship of severance payments is uncertain, holding constant the level of such transfers, and may well be negative, also applies under alternative modelling assumptions.

\footnotetext{
10 See Galdón-Sánchez and Güell (2003) on the consequences of mis-declaring the reasons for a dismissal.
} 


\section{Appendix: Signs of $\mathrm{H}_{\mathrm{W}}, \mathrm{H}_{\mathrm{N}}, \mathrm{E}_{\mathrm{ww}}$, and $\mathrm{E}_{\mathrm{w} S}$}

A sufficient condition for the derivatives of the modified Solow-condition $\mathrm{H}$ with respect to the wage $\mathrm{w}$ and employment $\mathrm{N}$ to be positive is $\mathrm{N} \geq 0.5$. Their derivatives are given by:

$$
\begin{gathered}
\mathrm{H}_{\mathrm{W}}=-\frac{\mathrm{EE}_{\mathrm{WW}}}{\left(\mathrm{E}_{\mathrm{W}}\right)^{2}}=-\frac{\mathrm{E}}{\left(\mathrm{E}_{\mathrm{W}}\right)^{2}}\left(-\frac{\left.\Omega_{\mathrm{E}} \Omega_{\mathrm{WE}} \mathrm{E}_{\mathrm{W}}-\Omega_{\mathrm{W}} \Omega_{\mathrm{EW}}-\Omega_{\mathrm{W}} \Omega_{\mathrm{EE}_{\mathrm{W}}} \mathrm{E}_{\mathrm{E}}\right)^{2}}{\left(\Omega_{\mathrm{W}} \Omega_{\mathrm{E}}\right.}\left(2 \Omega_{\mathrm{WE}}+\mathrm{E}_{\mathrm{W}} \Omega_{\mathrm{EE}}\right)=\frac{\mathrm{E}}{\mathrm{E}_{\mathrm{W}} 2 \Omega_{\mathrm{WE}}}\left(2 \mathrm{c}^{\prime \prime}(\mathrm{E})(1+\mathrm{b} \sigma)-\mathrm{E}_{\mathrm{W}} \mathrm{c}^{\prime \prime}(\mathrm{E}) \frac{1-2 \mathrm{~N}}{1-\mathrm{N}}\right)>0\right. \\
\mathrm{H}_{\mathrm{N}}=\frac{\mathrm{E}_{\mathrm{N}} \mathrm{E}_{\mathrm{W}}-\mathrm{EE}_{\mathrm{WN}}}{\left(\mathrm{E}_{\mathrm{W}}\right)^{2}}>0, \text { since } \\
\mathrm{E}_{\mathrm{WN}}=\frac{-\Omega_{\mathrm{E}} \Omega_{\mathrm{WE}} \mathrm{E}_{\mathrm{N}}+\Omega_{\mathrm{W}}\left(\Omega_{\mathrm{EN}}+\Omega_{\mathrm{EE}} \mathrm{E}_{\mathrm{N}}\right)}{\left(\Omega_{\mathrm{E}}\right)^{2}} \\
=\frac{\mathrm{E}_{\mathrm{N}} \Omega_{\mathrm{W}}}{\left(\Omega_{\mathrm{E}}\right)^{2}(1-\mathrm{N})}\left[\frac{\mathrm{c}^{\prime}(\mathrm{E})}{(1-\mathrm{N}) \mathrm{E}_{\mathrm{N}}}-\mathrm{c}^{\prime \prime}(\mathrm{E})(1-2 \mathrm{~N})\right]-\frac{\mathrm{E}_{\mathrm{N}} \mathrm{c}^{\prime \prime}(\mathrm{E})(1+\mathrm{b} \sigma)}{\Omega_{\mathrm{E}}}>0
\end{gathered}
$$

The derivative of marginal effort $\mathrm{E}_{\mathrm{W}}$ with respect to minimum severance payment $\mathrm{S}$ is:

$$
\begin{aligned}
\mathrm{E}_{\mathrm{WS}} & =-\frac{\Omega_{\mathrm{E}} \Omega_{\mathrm{WE}} \mathrm{E}_{\mathrm{S}}-\Omega_{\mathrm{W}} \Omega_{\mathrm{ES}}-\Omega_{\mathrm{W}} \Omega_{\mathrm{EE}} \mathrm{E}_{\mathrm{S}}}{\left(\Omega_{\mathrm{E}}\right)^{2}} \\
& =\beta \frac{-\Omega_{\mathrm{E}} \Omega_{\mathrm{WE}} \mathrm{E}_{\mathrm{W}}+\Omega_{\mathrm{W}} \Omega_{\mathrm{EW}}+\Omega_{\mathrm{W}} \Omega_{\mathrm{EE}} \mathrm{E}_{\mathrm{W}}}{\left(\Omega_{\mathrm{E}}\right)^{2}}=\mathrm{E}_{\mathrm{WW}} \beta<0
\end{aligned}
$$

Since $\Omega_{\mathrm{E}}, \Omega_{\mathrm{WE}}, \Omega_{\mathrm{EE}}, \mathrm{E}_{\mathrm{W}}>0$ from (6) and (8) and the assumptions on $\mathrm{c}(\mathrm{E})$, while $\Omega_{\mathrm{W}}<0$, $\mathrm{E}_{\mathrm{WW}}, \mathrm{E}_{\mathrm{WS}}<0$ obtains.

\section{References}

Akerlof, G. A. and Yellen, J. L. (1985), "A Near-Rational Model of the Business Cycle with Wage and Price Inertia", The Quarterly Journal of Economics, 100: 823-838.

Altenburg, L. and Straub, M. (1998), "Unemployment Benefits in a Unionized Economy with Efficiency Wages", Oxford Economic Papers, 50: 726-746.

Belot, M., Boone, J. and van Ours, J. C. (2006), "Welfare Improving Employment Protection", Economica, forthcoming.

Bentolila, S. and Bertola, G. (1990), "Firing Costs and Labor Demand: How Bad is Eurosclerosis?", Review of Economic Studies, 57: 381-402.

Bertola, G. (1999), "Microeconomic Perspectives on Aggregate Labor Markets", 2985-3028, in: Ashenfelter, O. and Card, D. C. (eds.), Handbook of Labor Economics, IIIC, Amsterdam et al.: Elsevier.

Booth, A. L. (1997), "An Analysis of Firing Costs and Their Implications for Unemployment Policy", 359-388, in: Snower, D. J. and de la Dehesa, G. (eds), Unemployment Policy:

Government Options for the Labour Market, Cambridge et al.: Cambridge University Press. 
Burda, M. C. (1992), "A Note on Firing Costs and Severance Benefits in Equilibrium Unemployment", Scandinavian Journal of Economics, 94: 479-489.

Carter, T. J. (1998), "Minimum Wage Laws: What Does an Employment Increase Imply about Output and Welfare?", Journal of Economic Behavior and Organization, 36: 473-485.

Chang, J., Lin, C. and Lai, C. (1999), "The Unemployment and Wage Effects of Shifting to an Indirect Tax in an Efficiency Wage Model", The Economic Record, 75: 156-166.

Chatterji, M. and R. Sparks, R. (1991), "Real Wages, Productivity, and the Cycle: An Efficiency Wage Model", Journal of Macroeconomics, 13: 495-510.

Fella, G. (2000), "Efficiency Wages and Efficient Redundancy Pay", European Economic Review, 44: 1473-1490.

Galdón-Sánchez, J. E. and Güell, M. (2003), "Dismissal Conflicts and Unemployment", European Economic Review, 47: 127-139.

Garibaldi, P. and Violante, G. L. (1999), Severance Payments in Search Economies with Limited Bonding, Mimeo, University College London.

Garibaldi, P. and Violante, G. L. (2005), "The Employment Effects of Severance Payments with Wage Rigidities", The Economic Journal, 115 (No. 506): 799-832.

Goerke, L. (1997), "Taxes in an Efficiency Wage Economy in the Short-run and in the Longrun", Finanzarchiv, 54: 447-470.

Goerke, L. (2002a), "On Dismissal Pay", Labour Economics, 9: 497-512.

Goerke, L. (2002b), Taxes and Unemployment, Boston et al.: Kluwer Academic Publishers.

Hoel, M. (1990), "Efficiency Wages and Income Taxes", Journal of Economics/ Zeitschrift für Nationalökonomie, 51: 89-99.

Lazear, E. P. (1990), "Job Security Provisions and Employment", The Quarterly Journal of Economics, 105: 699-726.

Lindbeck, A. and Snower, D. J. (2001), "Insiders versus Outsiders", Journal of Economic Perspectives, 15, 165-188.

Lockwood, B. and Manning, A. (1993), "Wage Setting and the Tax System", Journal of Public Economics, 52: 1-29.

Millard, S. P. and Mortensen, D. T. (1997), "The Unemployment and Welfare Effects of Labour Market Policy: A Comparison of the USA and the UK", 545-572, in: Snower, D. J. and de la Dehesa, G. (eds), Unemployment Policy: Government Options for the Labour Market, Cambridge et al.: Cambridge University Press.

OECD (1999), "Employment Protection and Labour Market Performance", 47-132, in: Employment Outlook, Paris.

OECD (2004), "Employment Protection Regulation and Labour Market Performance", 61125, in: Employment Outlook, Paris.

Pisauro, G. (1991), "The Effect of Taxes on Labour in Efficiency Wage Models", Journal of Public Economics, 46: 329-345.

Pisauro, G. (2000), "Efficiency Wages, Fixed Employment Costs, and Dual Labor Markets", Labour, 14: 213-244.

Pissarides, C. A. (2000), Equilibrium Unemployment Theory, 2nd. ed., Cambridge (Mass.) and London: The MIT Press.

Pissarides, C. A. (2001), "Employment Protection", Labour Economics, 8: 131-159.

Saint-Paul, G. (1995), "Efficiency Wage, Commitment and Hysteresis", Annales D'Economie et de Statistique, 37/8: 39-53.

Sanfey, P. J. (1995), "Insiders and Outsiders in Union Models", Journal of Economic Surveys, 9: 255-284. 
Shapiro, C. and Stiglitz, J. E. (1984), "Equilibrium Unemployment as a Worker Discipline Device", American Economic Review, 74: 433-444.

Solow, R. M. (1979), "Another Possible Source of Wage Stickiness", Journal of Macroeconomics, 1: 79-82.

Staffolani, S. (2002), "Firing Costs, Efficiency Wages and Unemployment", Labour, 16: 803830. 